\title{
Outlook of Consumers towards Online Pharmacies: Roles of Performance Expectancy, Effort Expectancy and Adoption Intention
}

\author{
Effulgence \\ Vol. 19, No. 1 \\ January - June, 2021 \\ Rukmini Devi Institute of Advanced Studies \\ E-mail : effulgence@rdias.ac.in, Website : www.rdias.ac.in \\ http://effulgence.rdias.ac.in/user/default.aspx \\ https://dx.doi.org/10.33601/effulgence.rdias/v19/i1/2021/16-26
}

\author{
Mr. Sanjeev Saraswat ${ }^{1} \measuredangle$ \\ Prof. (Dr.) R.K. Jain ${ }^{2}$ \\ Prof. (Dr.) Suvijna Awasthi ${ }^{3}$
}

\begin{abstract}
The transforming global scenario with impacts like Covid-19 are causing consumer buying shift from traditional purchase behaviour to online purchase behaviour. The present study proposed the unique linkage of performance expectancy and effort expectancy towards consumers' adoption intention towards online pharmacy platform in Indian context. The study involved 350 survey participants from national capital region of India and application of stepwise hierarchical multiple regression technique to explore empirical relationships among the study constructs proposed on the bases of previous literature. The performance expectancy and effort expectancy of Indian online users found to influence their adoptive behaviour significantly. The study visualized multiple findings and results of high worth for scholars and industry practitioners.
\end{abstract}

Keywords: Performance Expectancy, Effort Expectancy and Adoption Intention, Online Pharmacies, Online Consumer Behaviour.

\section{INTRODUCTION}

$\mathrm{O}$ nline medical services have been evolved out from among the critically significant aspects in today's societal climate. As far as statistical analysis is considered, medical care expenses expanded by 4.6percent from 2018 to 2019, arriving at an aggregate of $\$ 3.8$ trillion, or $\$ 11582$ per individual by (Centers for Medicare and Medicaid Services, U.S;
2020. According to this statistics, medical services use is anticipated to keep ascending annually consistently during 2014 to 2024, at a normal pace of 5.8 percent. In Indian context, the funds allocated by government of India for the Department of Health and Family Welfare witnessed a hike to Rs 65,001 crore in FY21 from Rs 37,061 crore in FY17 (Financial Express, 2020). In accordance with the mentioned extended development, the controlling state administrative authorities must give more

1. Research Scholar, School of Studies in Management, Jiwaji University, Gwalior, Sanjeevsaraswat78@gmail.com

2. Professor, Commerce Department MLB college, Jiwaji University, Gwalior

3. Research Center Dean, School of Studies in Management, Jiwaji University, Gwalior 
prominent consideration to their medical care venture (Mou and Shin, 2018).

The authors in this research study emphasized over the increasing inclination of consumers' towards internet based platforms for buying products and services with their rising exposure of online shopping. This also further leads to the reduction of the extents of confusions and risk based avoidance behaviour of buyers'. As a result, the overall intention of consumers' performing internet based buying is expected to be increased (Soopramanien, 2011).

In the advanced computerized period medical services are witnessing expanding utilization of online data from the web in spite of the change in its quality and dependability. On-line data is as a rule progressively used to advance patient selfadministration and improve correspondence between wellbeing experts and patients (Water worth and Honey, 2018).An interesting research study indicated that the domestic and international online platforms well showcase their corresponding affordable products which lead to overcoming the barriers of electronic buying dilemmas lying in way of pushing consumers' towards online shopping (Pal et al., 2015).

In a benchmark study conducted by Chanana and Goele (2012) on the exploration of potential of development of online business in future in India, the researchers found that the e-commerce based online business will expand many folds in the arriving long term in rapidly growing Indian industry. The authors further indicated the significance of various determinants that may contribute significantly in the growth of Indian online business and trade. Since, the study included the orientation of consumers towards online business in Indian context; it can be argued that the online pharmaceutical platforms in India may also focus on exploring relevant determinants that may conclusively ignite the growth of online pharmacies in India.
This paper endeavours to examine attitudinal factors that add to buyer acknowledgment of online drug store in India. The methodology utilized is the unified theory of acceptance and use of technology (UTAUT) method. Performance Expectancy alludes to how much an individual accepts that utilizing the framework will support the person in question to achieve gains in work execution. Effort Expectancy eludes to the level of simplicity related to the utilization of the online platform (Venkatesh et. al., 2003).

The reason for this investigation was to decide the quality of the indicators imagined from UTAUT model as performance expectancy and effort expectancy on adoption intention towards online drug stores in India.

\section{LITERATURE REVIEW}

Studies propose that expectations and ability by and large decide people's genuine practices (e.g., Cronan, Mullins, and Douglas, 2018). As recommended by the Theory of Reasoned Action (Fishbein and Ajzen, 1975), expectation/ability to utilize is the fundamental determinant of consumers' genuine conduct. In any case, understanding the components that impact consumers' eagerness is an unpredictable cycle. The three categorized study streams ease of understanding, in formativeness, and involving qualities were found to be explaining the online buying behavior of consumers (Demangeot \& Broderick, 2010). In a recent study, Dhimanet. al. (2019) suggested the significant roles of effort expectancy and performance expectancy in supporting the contribution of individual innovation towards adoptive behaviour in case of smart phone based fitness app users.

The builds of social influence, performance expectancy, and effort expectancy that are derived from UTAUT framework remained quite evident indicators of adoptive behaviors to utilize ARTS, with performance expectancy displaying the most grounded predictor, as demonstrated by the 
outcomes of the investigation (Madigan et al., 2017). The researchers (Walrave et al., 2020) studied 1500 participants in Belgium and identified the adoptive behaviour of mobile phone users towards mobile apps that helps in tracking people diagnosed with COVID-19. The researchers found that 48.70 percent of the study respondents shows their interest towards utilization of the related mobile app and the performance expectancy was the strongest predictor of the adoption intention of these study participants.

Venkatesh et al. (2003) capitalized eight innovation acknowledgment models in order to support the plan of projecting UTAUT-TAM-TPB (Taylor and Todd 1995); the Technology Acceptance Model (TAM) (Davis model; involving the Social Cognitive Theory or SCT by Bandura, 1986) (Davis, 1989); Model of PC Utilization (MPCU) (Thompson et al. 1991);Theory of Planned Behaviour (TPB) (Ajzen 1991);Innovation Diffusion Theory (IDT) (Rogers 1995); Theory of Reasoned Action (TRA) (Fishbein and Ajzen 1975); and Motivational Model (MM) (Davis et al., 1992). Yang (2010) studied Unified Theory of Acceptance and Use of Technology (UTAUT) framework within the conjunction of attitude and hedonic performance expectancy to study adoption intention 400 mobile phone users and found that hedonic and utilitarian and hedonic performance expectancy is significantly influenced by effort expectancy. Further, it was found that hedonic expectancy served as the crucial most factor of the consumers' adoption intention.

The extent of convenient interaction of consumers towards the utilization of related platform corresponds to the consumers' effort expectancy. Venkatesh et al. (2003) suggested that large volume of online shopping consumers treat e-shopping as a straightforward operation, convenience to grasp technological up-gradation, the enhanced proportion of happiness of consumers is found to be as utilizing unique online services.

Performance expectancy emerged out as the key impressive directive thrust for consumers' usage attitude (Venkatesh et. al., 2012). A latest study on UTAUT by Duarte \& Pinho (2019) over mobile based health app users suggested that performance expectancy must be offered intense focus by researchers while exploring the adoption behaviour of consumers'. Also, The Effort Expectancy build inside each model is huge in both deliberate and obligatory use settings; in any case, everyone is noteworthy during the first time frame, turning out to be non-huge over a time of broadened and continued utilization (Venkatesh et al., 2003) that can be considered in consonance of past examinations (Thompson et al. 1991, 1994; Davis et al. 1989; Agarwal and Prasad 1997, 1998).Carter et al. (2008) Studied 250 respondents in 2007 to explore consumer adoption behaviour towards e-filing services using multiple regression analysis and found useful inferences regarding the effort expectancy and performance expectancy. Also, Zhou et al. (2010) studied the unified theory of acceptance and usage of technology (UTAUT) model for evaluating perception related to the online consumers and assessed the impact casted by innovation as well as task fit apart from the perception of the technology. The authors found that the performance expectancy of consumers possesses positive and significant relationship with user adoption also found that the technology task fit significantly influences consumers' performance expectancy.

According to Alshare \& Lane (2011), performance expectancy as well as effort expectancy emerged among varied core variables of UTAUT model. The researchers argued that theses constructs contribute major role towards consequence based acceptable and behavioral context of students. When the authors examined the behaviour of students towards ERP learning and practicing they found that the students' effort expectancy and performance expectancy contributed significantly towards the same. Also, one of the remarkable finding of their study was that the influential impact of effort expectancy was well above that of performance expectancy in the context of attitudinal aspect of 
students. The researchers recently found a positive and significant connection between adoptive behaviour and performance expectancy and effort expectancy (Puspitosari \& Hidayat, 2020).

A pool of studies conducted previously indicated the rise of mobile users and its role in revolutionising the buying pattern of users. The previous research study (Oh et al., 2009) also simultaneously highlighted that the features of mobile services such as the techniques and design related issues influences the performance and effort expectancies which further influences the travelling consumers' attitudinal and usage patterns. In an empirical study conducted on 369 Smart phone based apps users who were customers of flight tickets, Jeon et al. (2019) suggested that performance expectancy is a positive as well as significant determinant of consumer adoption intention towards booking flight tickets while using mobile phone based apps. The study found support from research works conducted in Indian context also since it is found that the Indian investors are increasingly interested towards doing business on online platforms (Goyal et. al., 2013).

The research works conducted previously justify the roles of performance expectancy and effort expectancy in influencing the online adoptive behaviour of consumers'. The research studies conducted in India also justify the same as illustrated above. Still, as far as Indian online pharmacies are concerned, there is a huge literature gap existing at present. Thus, the present study not only explored the online behaviour of Indian consumers, but also justifies the existing literature by diagnosing the relationships between online users' performance expectancy and effort expectancy (UTAUT model) and their adoption intention in the context of online pharmacies.

Thus, it is hypothesized that,

Hypothesis 1: Effort expectancy influences adoption intention positively and significantly.
Hypothesis 2: Performance expectancy influences adoption intention positively and significantly.

Hypothesis 3: Effort expectancy influences performance expectancy positively and significantly.

Further, the following figure graphically represents the proposed study model indicating the associations of performance expectancy, effort expectancy, and adoption intention.

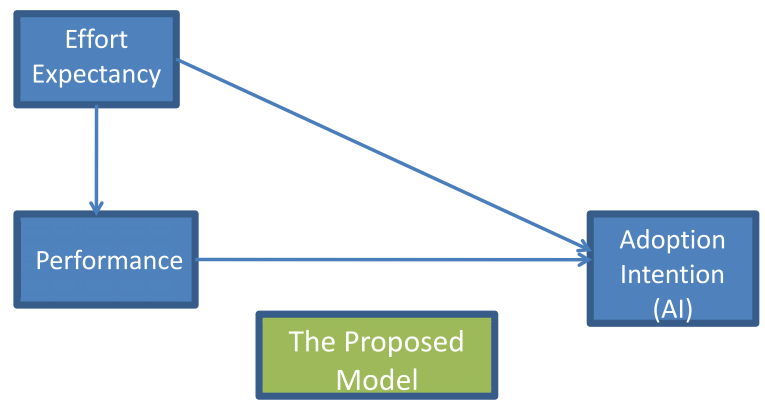

Figure 1 : The Proposed Model

\section{DATA COLLECTION}

The study respondents included people doing online purchase of medicines from the India's national capital region (NCR). The researchers successfully received371 questionnaires back from the contacted respondents. Also, as a part of data editing process, 21 inappropriate responses were excluded from the received questionnaires, and finally the researchers used350 high quality responses in data analysis process. The survey participants' population attributes are depicted systematically across Table 1. Also, the constructs for performance expectancy and effort expectancy were adopted from Venkateshet. al. (2003) and adoption intention was adopted from Zhou et al. (2010). The Cronbach's Alpha of the scales was 0.73 for performance expectancy, 0.83 for effort expectancy, and 0.93 for adoption intention respectively. This shows the adequate reliability of the used scales of measurement. 
Table 1 : Demographic Details

\begin{tabular}{|c|c|c|c|}
\hline Attribute & Alternative & Frequency & Percentile \\
\hline \multirow{2}{*}{ Gender } & Male & 294 & $84 \%$ \\
\cline { 2 - 4 } & Female & 56 & $16 \%$ \\
\hline \multirow{3}{*}{ Age } & $<25$ & 84 & $24 \%$ \\
\cline { 2 - 4 } & $25-35$ & 133 & $38 \%$ \\
\cline { 2 - 4 } & $35-45$ & 77 & $22 \%$ \\
\cline { 2 - 4 } & Above 45 & 56 & $16 \%$ \\
\hline \multirow{2}{*}{ Marital Status } & Married & 196 & $56 \%$ \\
\cline { 2 - 4 } & Unmarried & 154 & $44 \%$ \\
\hline
\end{tabular}

Note. $\mathrm{N}=350$.

Table 1 show that there exists both male and female respondents' participation in the sample population as $84 \%$ respondents were male and $16 \%$ respondents were female respectively. $62 \%$ of the sample respondents constitute young population who purchases medicine online either for themselves or for their family members as shown in table 1 that $62 \%$ of sample respondents are of less than 35 years of age. Also, $56 \%$ of respondents are married whereas $44 \%$ of respondents are unmarried, which shows that the study shows the opinions of both married and unmarried survey population.

Further, the table 2 represents that the sample population possesses adequate mean and thus it can be recommended that the study respondents responded adequately to the study constructs since the mean and standard deviation values are adequate enough.

Table 2 : Descriptive Statistics

\begin{tabular}{|c|c|c|}
\hline & Mean & Std. Deviation \\
\hline Gender & 3.69 & .23 \\
\hline Age & 3.21 & .56 \\
\hline Education & 3.12 & .75 \\
\hline Performance Expectancy & 2.52 & .64 \\
\hline Effort Expectancy & 2.33 & .78 \\
\hline Purchase Intention & 2.65 & .28 \\
\hline
\end{tabular}

\section{Data Analysis}

Note. $\mathrm{N}=350$.

Data collected was analysed using SPSS software. The correlations were analysed among the study constructs.

Table 3 : Correlations of Constructs

\begin{tabular}{|l|c|c|c|c|c|c|c|}
\hline & AVE & $\mathbf{1}$ & $\mathbf{2}$ & $\mathbf{3}$ & $\mathbf{4}$ & $\mathbf{5}$ & $\mathbf{6}$ \\
\hline $\mathbf{1}$ Gender & - & - & & & & & \\
\hline 2 Age & - & $.32^{* *}$ & 1 & & & & \\
\hline 3 Education & - & $.26^{* *}$ & $.46^{* *}$ & 1 & & & \\
\hline
\end{tabular}




\begin{tabular}{|l|c|c|c|c|c|c|c|}
\hline 4 Performance Expectancy & .65 & -.01 & -.02 & .03 & 1 & & \\
\hline 5 Effort Expectancy & .66 & -.04 & .05 & .05 & $.48^{* *}$ & 1 & \\
\hline 6 Adoption Intention & .68 & -.06 & .02 & $.21^{*}$ & $.26^{*}$ & $.32^{* *}$ & 1 \\
\hline
\end{tabular}

${ }^{*} \mathrm{P}<0.05, * * \mathrm{P}<0.01$

The researcher used stepwise hierarchical regression technique to evaluate the proposed impression over adoption intention of Indian customers towards online pharmacies in reference to their performance expectancy and effort expectancy. All the constructs possess AVE values as superior in comparison to the 0.5 which is the standard value and thus it can be argued that the convergent validity of the scales was established. Further, the square root values of the AVE values of all the scales were found to be higher than the values of the correlations of all the corresponding scales, and therefore it can be referred that the discriminant validity of the scales were also established.

Table 4 : Stepwise Hierarchical Regression Method for Study Constructs

\begin{tabular}{|c|c|c|c|c|c|c|c|c|c|c|}
\hline \multicolumn{11}{|c|}{ Analyzed Indicators for Proposed Structures } \\
\hline \multirow[b]{2}{*}{$\begin{array}{l}\text { Proposed } \\
\text { Structure }\end{array}$} & \multirow[b]{2}{*}{$\begin{array}{c}\mathbf{R} \\
\text { Value }\end{array}$} & \multirow[b]{2}{*}{$\begin{array}{l}\text { RSq. } \\
\text { Value }\end{array}$} & \multirow[b]{2}{*}{$\begin{array}{l}\text { Adj.RSq. } \\
\text { Value }\end{array}$} & \multirow[b]{2}{*}{\begin{tabular}{|c} 
Estimates' \\
St. Error
\end{tabular}} & \multicolumn{5}{|c|}{ CS } & \multirow[b]{2}{*}{ DB } \\
\hline & & & & & $\Delta \mathrm{RSq}$ & $\Delta \mathrm{F}$ & DF1 & DF2 & $\Delta \mathrm{F}^{\mathrm{S}}$ & \\
\hline 1 & $.102^{\mathrm{a}}$ & .010 & .008 & .62573 & .010 & 4.680 & 1 & 349 & .031 & \\
\hline 2 & $.154^{\mathrm{b}}$ & .024 & .019 & .62216 & .013 & 6.164 & 1 & 348 & .013 & \\
\hline 3 & $.250^{c}$ & .063 & .056 & .61032 & .039 & 18.556 & 1 & 347 & .000 & 1.839 \\
\hline \multicolumn{11}{|c|}{ a. Independent variable: Education } \\
\hline \multicolumn{11}{|c|}{ b. Independent variables: Education, performance expectancy } \\
\hline \multicolumn{11}{|c|}{ c. Independent variables: Education, performance expectancy, effort expectancy } \\
\hline \multicolumn{11}{|c|}{ d. Dependent Variable: Adoption intention } \\
\hline
\end{tabular}

Note: Rsq.: R Square, Adj. RSq.: Adjusted R Square, CS: Change Statistics; $\Delta$ RSq: R Square Change, $\Delta \mathrm{F}$ : F Change, DF: Degree of Freedom, $\Delta \mathrm{F}^{S}$ : Significant F Change, DB: Durbin-Watson

The researcher used stepwise hierarchical regression technique to assess the individual impacts of predictors on adoption intention of consumers as shown in table 4. In first step, demographic characteristics were entered as shown in Model 1 of the table 4. Further, performance expectancy was entered in step 2as shown in Model 2 of the table 4. Finally, effort expectancy was entered in next step as shown in Model 3 of the table 4. 
Table 5 : Analysis of Variance (ANOVA) of Constructs

\begin{tabular}{|c|c|c|c|c|c|c|}
\hline \multicolumn{7}{|c|}{ ANOVA $^{a}$} \\
\hline \multicolumn{2}{|c|}{ Proposed Structure } & SSq & DF & MS & $\mathbf{F}$ & S. \\
\hline \multirow{3}{*}{1} & $\mathrm{Rg}$ & 1.833 & 1 & 1.833 & 4.680 & $.031^{\mathrm{b}}$ \\
\hline & Residual & 175.799 & 349 & .392 & & \\
\hline & Total & 177.632 & 350 & & & \\
\hline \multirow{3}{*}{2} & $\mathrm{Rg}$ & 4.219 & 2 & 2.109 & 5.449 & $.005^{c}$ \\
\hline & Residual & 173.413 & 348 & .387 & & \\
\hline & Total & 177.632 & 350 & & & \\
\hline \multirow{3}{*}{3} & $\mathrm{Rg}$ & 11.130 & 3 & 3.710 & 9.960 & $.000^{\mathrm{d}}$ \\
\hline & Residual & 166.502 & 347 & .372 & & \\
\hline & Total & 177.632 & 350 & & & \\
\hline \multicolumn{7}{|c|}{ a. Dependent Variable: Adoption intention } \\
\hline \multicolumn{7}{|c|}{ b. Independent variable: Education } \\
\hline \multicolumn{7}{|c|}{ c. Independent variables: Education, performance expectancy } \\
\hline \multicolumn{7}{|c|}{ d. Independent variables: Education, performance expectancy, effort expectancy } \\
\hline
\end{tabular}

Note: SSq.:Sum of Squares, DF: Degree of Freedom, S: Significance, MS: Mean Square, Rg: Regression.

Table 5 shows the analysis of variance (ANOVA) of constructs. The significance values for both the stages indicating the impact of performance expectancy alone and performance expectancy and effort expectancy shows that while performance expectancy alone influences consumers' intention for online pharmacies, it becomes more significant when effort expectancy comes into the model. This also justifies the appropriateness of the study model taking into consideration the study of influences of performance expectancy and effort expectancy together towards consumers' adoption intention.

\section{FINDINGS \& DISCUSSION}

The table 3 shows positive association among the three considered study variables as effort expectancy, performance expectancy, as well as adoption intention are positively associated with each other. This supports the argument of researcher (Venkatesh et. al., 2003) that the two unique constructs proposed in UTAUT model positively associates with consumers' adoption behaviour towards online pharmacies in India. Performance expectancy is found to be positively associated with adoption intention $\left(.26^{*}\right)$ and also, effort expectancy is found to be positively associated with adoption intention $\left(.32^{*}\right)$. This leads to the acceptance of hypotheses 1 and 2 respectively. The correlation study also supports the proposed assumption of the present study that performance expectancy and effort expectancy are positively associated with each other.

Also, from table 4 the model shows significant impact of gender and education on consumers' behaviour towards online pharmacy usage (R-square $=0.10, \mathrm{p}<0.05)$. Further, performance expectancy together with respondent's demographic characteristics shows significant impact on consumers' behaviour towards online pharmacy usage (R-square $=0.02, p<0.05)$ as shown in Model 2 of the table 4 . Finally, effort expectancy shows that it casts significant influence on consumers' behaviour towards online pharmacy usage (R-square 
$=0.06, \mathrm{p}<0.00)$ as shown in Model 3 of the table 4 . The study results received support from previous literature also. This leads to the acceptance of hypothesis 3.

The findings of the study found adequate support from previous literature also. J. H. Lee and Song (2013) conducted an empirical study to explore consumers' adoption intention towards the usage of Certified e-Document Authority (CeDA) support services and found that the performance expectancy was significantly associated with the consumers' behavior and simultaneously the authors found that the effort expectancy was significantly associated with the performance expectancy. This also opens a new area for entrepreneurship researchers as societal up gradations boost their confidence to launch new ventures (Mahajan \& Mahajan, 2020).Dahia \& Dangi (2020) also found in their study that leading IT major industries are on a rapind roll out of bringing revolutions among major IT based ventures in India.

The analytical study conducted by the researchers Cao and Niu (2019) suggested valuable insights over the mediating roles displayed by the effort expectancy and the performance expectancy across the association of the Alipay client reception and the specific circumstance. On the other hand, it is only the performance expectancy which mediated the associated of the Alipay client selection and the pervasiveness. These outcomes uphold the current examination findings and furthermore featured that future investigations in India may likewise investigate directing and mediating functions of the effort expectancy and performance expectancy. This empirical investigation well expanded the horizon of UTAUT framework (Venkatesh et. al., 2003) in the scenario of India's online pharmaceutical industry. The study has suggested many unique findings of the connectedness of the proposed variables performance expectancy, effort expectancy, and adoption intention of medicines using online pharmaceutical platforms. Also, the researchers may inculcated the consideration of psychological determinants such as psychological capital
(Upadhyay \& Kumar, 2019) in analysing the online consumption behaviour of Indian users to further elaborate the horizon of online consumption behavour literature.

The present study suggests Indian online pharmaceutical industry leaders to emphasize on enhancing the standards of online buying and selling process as per the customs and practices of India's traditional pharmaceutical retailers' practices and characteristics, supporting the conversion of buying and selling of online pharmacies products from traditional pharmacies, taking measures of building safety and security of online transactions, promoting ease of affordability and convenience of users such as including cash on delivery mode, and meeting commitments with respect to delivery schedules of medicines to clients. These findings also attracts the emphasis of industry leaders required to improve the quality of manpower (Kumar et. al., 2014) in pharma industries since research is an important part of pharma industry and online compatibility behaviour (Gulati et. al., 2020) is an added dimension in it as far as Indian context is concerned. Such measures will support the operational efficiency of performance expectancy and effort expectancy in enhancing adoption intention of consumers' towards online pharmacies in India.

\section{CONCLUSION}

This study successfully expanded the horizon of pharmaceutical industry in India in the purview of ecommerce industry in India. Since, the turbulence of time with on-going uncertainties such as Covid-19 scenario has shifted the way the business was done before, in a manner of people better preferring buying via online platforms. This study emphasized the growing demand of Indian consumers towards online buying of medicines. The researchers in the present study recommended online pharmacy marketers to focus on utilizing performance expectancy and effort expectancy measures to promote their online pharmacy business in India. 


\section{REFERENCES}

Ajzen, I. (1991) "The Theory of Planned Behavior," Organizational Behavior and Human Decision Processes (50:2), pp. 179-211.

Agarwal, R., and Prasad, J. (1997), "The Role of Innovation Characteristics and Perceived Voluntariness in the Acceptance of Information Technologies," Decision Sciences (28:3), 1997, pp. 557-582.

Agarwal, R. and Prasad, J. (1998b), “The antecedents and consequents of user perceptions in information technology adoption". Decision Support Systems, Vol. 22 No. 1, pp. 15-29.

Alshare, K. A., \& Lane, P. L. (2011).Predicting student-perceived learning outcomes and satisfaction in erp courses: An empirical investigation. Communications of the Association for Information Systems, 28(1), 34.

Bandura, A. (1986). Social foundations of thought and action. Englewood Cliffs, NJ, 1986.

Carter, L., Schaupp, L., \& Evans, A. (2008). Antecedents to e-file adoption: The us perspective. Proceedings of the 41st Annual Hawaii International Conference on System Sciences (HICSS 2008), 216-216.

Cao, Q., \&Niu, X. (2019).Integrating contextawareness and utaut to explain alipay user adoption. International Journal of Industrial Ergonomics, 69, 9-13.

Chanana, N., \&Goele, S. (2012). Future of ecommerce in india. International Journal of Computing and Business Research.

Cronan, T. P., Mullins, J. K., \& Douglas, D. E. (2018).Further understanding factors that explain freshman business students' academic integrity intention and behavior: Plagiarism and sharing homework. Journal of Business Ethics, 147(1), 197-220.

Davis, F. D. (1989),"Perceived usefulness, perceived ease of use, and user acceptance of information technology", MIS Quarterly, 13(3) pp 319-340.

Davis, F. D., Bagozzi, R. P., and Warshaw, P. R. (1989). "User acceptance of computer technology: A comparison of two theoretical models". Management Science, 35(8), pp 982-1003.

Davis F., Bagozzi, R., and Warshaw, P. (1992),"Extrinsic and Intrinsic Motivation to Use Computers in the Workplace" .Journal of Applied Social Psychology, 22(14), pp1111- 1132.

Dahia, H. \& Dangi, H. K. (2020).Paytm- The Exemplar of Digital Revolution in the Indian Market, Effulgence, Vol. 18, No. 1, pp. 77-86. https://dx.doi.org/10.33601/effulgence.rdias/v 18/i1/2020/77-86

Demangeot, C., \& Broderick, A. J. (2010). Consumer perceptions of online shopping environments: A gestalt approach. Psychology \& Marketing, 27(2), 117-140.

Dhiman, N., Arora, N., Dogra, N., \& Gupta, A. (2019). Consumer adoption of smartphone fitness apps: An extended UTAUT2 perspective. Journal of Indian Business Research.

Duarte, P., \&Pinho, J. C. (2019).A mixed methods UTAUT2-based approach to assess mobile health adoption. Journal of Business Research, 102, 140-150.

Goyal A. K., Kumar D., \& Goyal S. (2013).Impact of Investor's Profile on Investment Decisions - A Critical Study. Effulgence, 11 (1), pp. 56-84. https://dx.doi.org/10.33601/effulgence.rdias/v 11/i1/2013/56-64

Gulati C., Upadhyay Y., \&Mathur G. (2020).Congruence and Internalization as predictor of Citizenship Behaviour: Empirical Investigation using PLS. Effulgence, Vol. 18, No. 1 , pp. 11-22. https://dx.doi.org/10.33601/effulgence.rdias/v 18/i1/2020/11-22

India spending more on healthcare now, but yet not as much as others; here's how much US, China spend. (2020, April 8). The Financial Express.https://www.financialexpress.com/eco nomy/india-spending-more-on-healthcare-nowbut-yet-not-as-much-as-others-heres-how-muchus-china-spend/1922253/

Kumar D., GoyalS.,\&Mahlhotra S. (2014). Impact of HRA on Productivity of Indian Industries: An Empirical Analysis. Effulgence, Vol. 12, No. 1, 
pp. 56-61.

https://dx.doi.org/10.33601/effulgence.rdias/v 12/i1/2014/56-61

Lee, J.-H., \& Song, C.-H.(2013). Effects of trust and perceived risk on user acceptance of a new technology service. Social Behavior and Personality: An International Journal, 41(4), 587-597.

Madigan, R., Louw, T., Wilbrink, M., Schieben, A., \&Merat, N. (2017). What influences the decision to use automated public transport? Using utaut to understand public acceptance of automated road transport systems. Transportation Research Part F: Traffic Psychology and Behaviour, 50, 55-64.

Mou, J., \& Shin, D. (2018). Effects of social popularity and time scarcity on online consumer behaviour regarding smart healthcare products: An eyetracking approach. Computers in Human Behavior, 78, 74-89.

NHE Fact Sheet. (2020), CMS. (n.d.). Retrieved from https://www.cms.gov/Research-Statistics-Dataand-Systems/Statistics-Trends-and-Reports / NationalHealthExpendData/NHE-Fact-Sheet

Thompson, R. L., Higgins, C. A., and Howell, J. M. (1991) "Personal Computing: Toward a Conceptual Model of Utilization," MIS Quarterly (15:1), pp. 124-143

Thompson, R. L., Higgins, C. A., and Howell, J. M. (1994) "Influence of Experience on PersonalComputer Utilization: Testing a Conceptual Model" Journal of Management InformationSystems, Vol. 11 No. 1, pp. 167 - 187.

Fishbein, M., and Ajzen, I. (1975),"Belief, Attitude, Intention and Behavior: An Introduction to Theory and Research", Addison-Wesley, Reading, MA.

Jeon, H.-M., Ali, F., \& Lee, S.-W.(2019). Determinants of consumers' intentions to use smartphones apps for flight ticket bookings. The Service Industries Journal, 39(5-6), 385-402.

Oh, S., Lehto, X. Y., \& Park, J. (2009). Travelers' intent to use mobile technologies as a function of effort and performance expectancy. Journal of Hospitality Marketing \& Management, 18(8),
765-781.

Puspitosari, R., \&Hidayat, A. (2020).Determinants of Mobile Banking Adoption Behavior in SubUrban Areas. American International Journal of Business Management, 3(10), 59-71

Rogers, E.M. (1995), Diffusion of Innovation, Free Press, New York, NY.

Soopramanien D. (2011). Conflicting attitudes and scepticism towards online shopping: the role of experience, International Journal of Consumer Studies, Vol. 35 Issue 3, pp. 338-347

Taylor, S., and Todd, P. A.(1995a) "Assessing IT Usage: The Role of Prior Experience," MIS Quarterly (19:2), pp. 561-570.

Venkatesh, V., Morris, M.G., Davis, G.B., Davis, F.D., 2003. User acceptance of information technology: toward a unified view. MIS Q. 425-478.

Venkatesh, V., Thong, J.Y., Xu, X., 2012. Consumer acceptance and use of information technology: extending the unified theory of acceptance and use of technology. MIS Q. 157-178.

Waterworth, S., \& Honey, M. (2018). On-line health seeking activity of older adults: An integrative review of the literature. Geriatric Nursing, 39(3), 310-317.

Mahajan, T., \& Mahajan, T. (2020).Comparative study of students' entrepreneurship intentions with reference to North-India Region. Effulgence, 18(2), 58-64. https://dx.doi.org/10.33601/effulgence.rdias/v 18/i2/2020/58-64.

Pal, D., Vanijja, V., \& Papasratorn, B. (2015). An empirical analysis towards the adoption of NFC mobile payment system by the end user. Procedia Computer Science, 69, 13-25

Walrave, M., Waeterloos, C., \&Ponnet, K. (2020).Ready or Not for Contact Tracing? Investigating the Adoption Intention of COVID-19 Contact-Tracing Technology Using an Extended Unified Theory of Acceptance and Use of Technology Model.Cyberpsychology, Behavior, and Social Networking.

Upadhyay, Y., \& Kumar, D. (2019). Psychological capital in indian industries: A demographic assessment. Effulgence, 17(1), 78-85. 
https://dx.doi.org/10.33601/effulgence.rdias/v 17/i1/2019/78-85

Yang, K. (2010). Determinants of us consumer mobile shopping services adoption: Implications for designing mobile shopping services. Journal of Consumer Marketing.

Zhou, T., Lu, Y., \& Wang, B. (2010).Integrating TTF and UTAUT to explain mobile banking user adoption. Computers in Human Behavior, 26(4), 760-767. 